\title{
Oxycodone Hydrochloride/Naloxone Hydrochloride Prolonged-release Tablet
}

National Cancer Institute

\section{Source}

National Cancer Institute. Oxycodone Hydrochloride/Naloxone Hydrochloride Prolonged-

release Tablet. NCI Thesaurus. Code C103824.

A prolonged-release tablet formulation composed of the hydrochloride salt form of the opioid receptor agonist oxycodone and the hydrochloride salt form of the opioid receptor antag onist naloxone which may produce analgesia while relieving opioidmediated gastrointestinal (GI) side effects. Upon oral administration, oxycodone binds to opioid receptors, thereby mimicking the effects of endogenous opiates to provide analgesia. As naloxone is very poorly absorbed, this agent binds locally to opiate receptors in the Gl tract, thereby preventing oxycodone from binding to these receptors. This relieves the opioid-related side effects on the Gl tract, including opioid-induced constipation. 